M. Ibatullin, candidate of economic sciences

National University of Life and Environmental Sciences of Ukraine

\title{
WORLD TRENDS IN SWINE BREEDING
}

The purpose. Development of theoretical rules and practical references concerning assessment of world trends in swine breeding. Methods. Dialectic method of scientific knowledge, analysis and synthesis; systemic generalization. Results. Features of the world market of swine breeding are studied: state of world trade by pork depends on scales of production of meat, level of volumes of its processing, and also preferences of users. Development of that market depends on economic and administrative methods of protection of domestic market, sanitarian norms, and dynamics of prices for grain. Conclusions. Liberalization of trade and improvement of technique of growing of pigs promoted double increase of volumes of trade in the last decades, intensification of concurrence in the market and monopolization.

Key words: production, production of pigs, breeds, meat.

Formulation of the problem. Pork belongs to the most economically efficient branches of animal husbandry, which is due to the biological characteristics of animals, in particular, high productivity and energy value of produced products, short production times for slaughter, and also characterized by high requirements for feed. This branch of livestock farming has intensive development in East Asia (China), Europe, America. It is obvious that the most important habitats of pig breeding tend to densely populated areas and industrial centers, to places of cultivation and processing of grain, and also meat processing enterprises. In the last decade, world-wide production of pork by leading national producers has increased, and experts estimate, exceeding 110 million tons. Thus, world production of pork will grow by an average of $2 \%$ annually compared to the achieved level.

Material and methods of research. The paper uses the dialectical method of scientific knowledge, analysis and synthesis;

System generalization. The purpose of the research is to develop theoretical principles and practical recommendations for the evaluation of world trends in the production of pig products.

The main research material. Currently, the share of pork in the world meat production structure is the largest, and recently stabilized at the level of 
almost $40 \%$. In the second place - poultry, the share of which in the total production is about $30 \%$, beef -25 , lamb - 4,8, other types of meat $-1,8 \%$. Experts predict that by 2020 poultry meat will gradually gain market share in pork, but it will remain at 40\% in the coming years. During $2006-2013$ there was a gradual increase in the volume of world production of pork - an average of $3.4 \%$ per year. At the same time, poultry meat production increased by more than $30 \%$ during this period, which led to a decrease in the share of pork production from 40.6 in 2006 to $35.1 \%$ in 2013 . This situation can be explained by the technological and economic benefits of production of meat. Poultry as compared to pork, in particular, high return on investment in the poultry industry, animal breeding, and so on. Ultimately, the price level for poultry was lower than that of slaughtering pigs, which led to an increase in demand, in particular end-users - low-income people. The cultivation of pigs in the leading countries of the world is mainly concentrated in farms, which operate both within the integrated structures and on an individual basis. However, in recent years, due to the intensification of intraindustry concentration and pig breeding specialization in all economically developed countries, there is an enlargement of farms engaged in the cultivation of pigs. So, in the United States, growing and fattening pigs are traditionally used on farms that produce their own forages, as well as in large specialized complexes of industrial type. In this case, the first group of producers is located in the so-called grain belt, and the second - in areas of deficit of pork [1]. Large farms usually provide a relatively high level of intensity through a well-established chain of production, as well as long-term partnerships with feed mills and meat processing companies. An important role is played by contractual relations with local farmers regarding the lease of breeding sows, as well as the joint organization of large specialized breeding companies for the production of piglets and the removal of a purebreed herd of meat of pigs. On the basis of such agreement, the permanent control of the farmer's activity is carried out. At the same time, agricultural commodity producers receive material and production support, as well as scientific counseling. From cultivating farm animals. All expenses the company compensates from the total proceeds of the farmer for the period specified in the contract. Transportation of pigs in the leading countries of the world is organized with the help of specialized motor transport. For example, in Denmark, the Netherlands, the USA transportation is carried out by specialized transport companies, which enter into contracts with manufacturers on a long-term basis. It should be noted that in some countries transportation is carried out by processing enterprises that hold a specialized transport fleet or with the involvement of services of specialized transport companies. In most industrialized countries, a significant role in the 
production of pork belongs to small agricultural producers. So, in China, more than $90 \%$ of the total volume is produced by small farms, which hold no more than 3 sows per household. In Poland, the share of farms accounts for $70 \%$ of the population, in Hungary - about $50 \%$.

The study found that the world's production of pork is dominated by countries such as China, the USA, Canada, Brazil and the EU, which, in particular, accounts for three-quarters of world exports of these products. It should be noted that the intensive type of development of pig breeding in these countries is determined by the effective state policy to support the development of both meat production and the agrarian sector as a whole. It is obvious that in most countries, public financial support for pig production is provided to provide the population with pork at affordable prices, and also provides for the profitability of commodity producers to ensure enhanced reproduction. We distinguish the characteristic features of the world market of pig products: the state of world trade in pork depends on the scale of meat production, the level of its processing, as well as the benefits of consumers; the development of this market depends on such restrictive factors as economic and administrative measures to protect the domestic market, sanitary norms, and the dynamics of grain prices; Trade liberalization and improved pig production have contributed to a 2 -fold increase in trade over the past decade; increasing competition in the market and monopolization. The study of the world market situation of pork made it possible to establish its relative stability. Thus, pig breeding has developed quite stable in conditions of world consumption growth, growing purchasing power of the population, despite the outbreaks of animal diseases, the rapid rise in energy and food prices. So, since 2009, crisis phenomena have affected the development of the pork market, in particular: the industrial relations have been affected by the crisis not only in the segment of international trade, but also in the relations between processing enterprises and agricultural commodity producers. The further development of economic relations was influenced by the readiness of the banking system to finance investment projects in livestock farming, as well as a number of measures taken by the states to support and develop this sector. Thus, in 2013 the world produced 112.3 million tons of pork, which is $4.6 \%$ more than in 2010 . It should be noted that in 2013, 7 countries provided $72 \%$ of world production of pork (China, the USA, Germany, Spain, Brazil, Vietnam, Russian Federation). The world leader in the production of pork is China. In 2013, this country produced 53.8 million tonnes, or $47.9 \%$ of the world's production of pork. EU countries produce $19.5 \%$ of the world's total pork, or 21.9 million tonnes, the United States $-8.8 \%$, or 9.9 million tonnes. It should be noted that in 2013 Ukraine has ranked 24 th in the world in the production of pork. Thus, the 
production of pork in Ukraine in 2013 increased by $18.5 \%$ compared to 2010 and amounted to 748 thousand tons in live weight. Production of pork in China, which accounts for about half of the world's output, in 2013 compared to 2012 increased by $2.8 \%$ and reached its peak. Low growth rates are driven, first of all, by the low dynamics of demand, which in turn is associated with a slowdown in economic growth. In addition, the increase in feed costs negatively affects the efficiency of the sector. In 2012 due to low prices for pigs somewhat slowed down the process of its technical re-equipment, there were some tendencies for displacement of small enterprises from the market. In this regard, in 2013, the growth of the livestock population and the slight increase in slaughter of animals were noted only slightly in the previous years. At the same time, in China pig production rates are medium-sized, which tend to grow, as there is an increase in the number of innovative modern farms, which was also facilitated by state support to the industry's leadership of the country. It has been established that in recent years China has attracted the best breeds of pigs imported from the USA (Duroc, Yorkshire, Hampshire) and other countries (Big White, Landrace, etc.) into the sphere of production, which crosses with local Chinese hybrids that combine valuable qualities Chinese pigs (milk yield, multiple fertility, the possibility of using plant fodder) with the speed and meatiness of the best world pigs [3].

The next powerful pork producer is Brazil. Thus, pork production in this country in 2013 decreased by $1.3 \%$ against 2012 and by $0.5 \%$ by 2005 . This is due to a significant increase in fodder grain prices as compared to the increase in pork prices, which led to reducing the efficiency of Brazilian pig breeding. In view of this, the government began subsidizing grain auctions, extends the maturity of loans and introduces temporary tax incentives for producers [4]. Russia is a powerful pork producer in the world, which in 2013 increased its production by more than $10 \%$. The main factors in stimulating the development of pig breeding have been low prices for grain fodder, as well as effective state support. As a result, highly specialized agricultural enterprises producing pig products thanks to state support continue to increase production volumes, small ones - because of the low efficiency of production and the African swine fever epidemic suffered losses and forced to leave the market. It was found that the volume of pork production in the EU countries in 2013 decreased by $1.3 \%$ compared to 2012 . This situation was caused by rising feed prices, but another important reason was the strengthening of veterinary and sanitary requirements for the keeping of pigs. The need to comply with these requirements has led to restructuring of the sector, which resulted in the least productive farms turning down activities. It should be noted that the pace of reproduction of pigs in EU countries 
remained stable, however, the increase in feed costs led to a reduction in the mortality rate of animals. In 2013, the production of pork in the United States declined by $0.5 \%$ compared to 2012 . In a context of rising feed costs, producers are trying to minimize costs, which led to a decrease in piglet yields per sow, and a reduction in the slaughter weight of pigs. Pork production in Canada declined by $0.5 \%$ in 2013 as the high cost of feed and the decline in US demand for pigs had a negative impact on the positive trend of industry growth observed in early 2012 . It should be noted that the average weight of adult pigs in Canada is $129 \mathrm{~kg}$, in the USA $135 \mathrm{~kg}$. It is known that commodity pigs in the USA are mainly domestic and hybrid animals. In breeding work, the leading place is given to such local breeds as Duroc, Landrace, Hampshire. Improvement of productive characteristics is carried out by special stations by assessing the horses for the quality of offspring and selection of high-yielding ones. At the same time, work on the concentration and specialization of pig farms is underway. During the 15-year period, the total number of pig farms has decreased by $15 \%$, with the increase in the number of animals on large-scale farms. In Canada, $54 \%$ of farms operate in a production cycle that provides up to $80 \%$ of slaughtered stock. The reproducers for growing piglets up to $20 \mathrm{~kg}$ account for $8 \%$, and fattening $19 \%$. It should be noted that the pig farms of the USA, Canada, Germany, the Netherlands, the United Kingdom, etc. the countries develop in the conditions of high level of forage supply with constant improvement of rations by balancing fodders with the level of protein and energy, as well as the introduction of vitamin supplements, trace elements, amino acids, antibiotics. For feeding pigs use concentrated feed. Noteworthy is the development of pig breeding in Mexico, where state support for commodity producers compensated for higher food prices, while pork production in 2013 compared with 2012 increased by $3.6 \%$. Farmers engaged in breeding pigs continue to increase animal productivity through the introduction of innovative breeding technologies for those breeds that are better adapted to local conditions, as well as the introduction of modern management technologies while simultaneously increasing the stock of pigs. The organization of pork production in the Republic of Korea, where production volumes increase by $2.5 \%$ due to affordable prices for fodder grain, is of interest to domestic practices. However, due to the introduction of norms governing the placement of livestock farms, requirements for the maintenance of animals, manure utilization, and vaccination against foot-and-mouth disease, the further deterioration of the production of pig production was hampered [10].

It should be noted that virtually all leading countries, unlike Ukraine, have a multi-level channel for product promotion from manufacturer to consumer. The chain of promotion includes: transportation, auction, 
slaughter, processing enterprise, large wholesale company, retail trade. At the same time, significant changes in the sales of pigmeat products occurred during the last 20 years. On the one hand, this system was improved in the direction of expanding direct ties, which minimized the number of intermediaries. On the other hand, significant changes have occurred in prioritizing channels. Today, the role of sales of pigs in the form of contracting rural commodity producers with industrial and trading firms and farmer co-operation increased, while the share of sales of products through wholesale markets and auctions has declined significantly. However, it is precisely the current level of prices in wholesale markets that is the main benchmark for establishing contract prices and government-guaranteed prices [5]. Contract relations between the members of the agro-food chain are quite different in each country and depend on such factors as sales conditions, forms of economic stimulation and the number of participants. In this case, obligatory for all types of contracts is the definition of the volume of manufactured products, terms of delivery, price and methods of implementation. For violation of these conditions, the contract is punishable by penal sanctions. In many contracts the following are stipulated: size of farms, conditions of delivery of means of production, features of credit service. In the UK, contracts with a so-called moving price, which is calculated on the basis of a market rate, and it changes every month, are especially widespread. Under the terms of such an agreement, when pricing pork prices for feed are not indexed. In the Netherlands, most contracts are concluded on average for 3 years with a guaranteed minimum price and due to the slaughter weight of pigs $80-85 \mathrm{~kg}$. When working under a contractual system, a farmer often loses his economic independence, ensuring the full acceptance of the requirements of a vertically integrated association formed from feed mill, processing and trading enterprises. In this connection, in many countries there are farm cooperatives that help agricultural producers to gain real economic power. By acting as an instrument of antitrust, they form alternative sales channels for pig products. Cooperatives have the right to independently establish the estimated prices for products and means of production, veterinary services, etc. Usually they form the staff of management, they can change the price of sales of the final products of pig production, etc. Under the agreement with the sectoral cooperatives, the issue is resolved at the level of government bodies, which is why they distribute loans and subsidies provided by the state.

\section{Conclusions}

The generalization of the pig breeding industry in some countries of the world makes it possible to draw the following conclusions. Firstly, the pork 
market is one of the main sectors of the agro-food market of any country. The volumes of supply and demand for pigmeat depend on the development of agricultural production in each country, as well as on the optimal combination of measures of state regulation and market self-regulation, socio-economic status of the country. Secondly, high consumption indices in the leading countries of the world, such as the USA, the EU and others, are provided mainly due to the effective agrarian policy of the states, which involves their active participation not only in foreign economic activity but also solves the food security issues of each country. At the present stage, in spite of the crisis situation, world production of pork tends to grow steadily.

\section{Bibliography}

1. Paptsov A.H. Orhanyzatsyonno-эkonomycheskye y эkolohycheskye problemb myrovoho svynovodstva/A.H. Paptsov//Ahrarnaya Rossyya. - 2006. - № 3. - S. $14-17$.

2. Voskresenskyy S.B. Puty povыshenyya эffektyvnosty svynovodstva y proyzvodstva vыsokokachestvennoho myasa/S.B. Voskresenskyy, Yu.V. Tatulov, Y.S. Sus'//Vse o myase. - 2006. - № 4. - S. $25-28$.

3. Nemyyskyy S. Эkonomycheskye aspektы proyzvodstva svyney na otkorme v sovremennыkh rыnochnыkh uslovyyakh/S. Nemyyskyy, V. Pzhыbыl'skyy//Efektyvne tvarynnytstvo. — 2007. — № 2. - S. 23.

4. Pavlov A.A. Mezhkhozyaystvennaya kooperatsyya v svynovodstve y ee эkonomycheskaya эffektyvnost'/A.A. Pavlov, N.A. Dushkyna, A.A. Pavlov//Эkonomyka s.-kh. y pererabatıvayushchykh predpryyatyy. 2008. — № 4. - S. 55 - 57.

5. Hэdd Dzhon. O chem ne hovoryt sya $v$ uchebnykakh.../Dzhon Hэdd//Zhyvotnovodstvo Rossyy. - 2009. - № 2. - S. $43-47$.

6. Kopytets' N. Rynok svynyny: realiyi ta mozhlyvosti/N. Kopytets'//Myasnoy byznes. - 2010. - № 6. - S. $80-83$.

7. Rybalko V. Naukovi aspekty rozv"yazannya problemy defitsytu svynyny v Ukrayini/V. Rybalko//Tvarynnytstvo Ukrayiny. — 2006. — № 2. — S. $2-5$.

8. Svyatkyvskaya E. Myasnыe perspektyvы/E. Svyatkyvskaya//Myasnoy byznes. - 2008. — № 7. - S. $114-119$.

9. Shats'kyy V.V. Osoblyvosti rozvytku svynarstva ta vivcharstva v Ukrayini/V.V. Shats'kyy, S.M. Kolomiyets'//Pratsi Tavriys'koho derzh. ahro-tekhnoloh. un-tu: nauk. fakhove vydannya. - Melitopol', 2008. Vyp. 8, T. 8. - S. $123-128$. 